\title{
Factors Influencing Customer's Repurchase Intention of Go-Jek in Semarang, Indonesia
}

\author{
Mudiantono \\ Diponegoro University, \\ Debrina Andhike \\ Diponegoro University, \\ mumuk_undip@yahoo.co.id, \\ debrinandhike@gmail.com
}

\begin{abstract}
The emergence of GO-JEK is the beginning of many similar businesses. People are smart enough to compare the benefits that each company offers. Customer dissatisfaction is one of the reasons why people stop using a company's service. Thus, the company needs to be able to implement strategies in order to keep or increase customer interest in using services offered by GO-JEK.

This study aims to analyze how to increase the customers' intention to repurchase GO-JEK's services. The method used in collecting data is purposive sampling. This study has 180 samples that were collected through questionnaires. Questionnaires were distributed to the respondents who have ever tried using GO-JEK's services more than twice in Semarang, Indonesia. The data collected were processed using Structural Equation Modeling (SEM) through AMOS ver. 22.0 to test ten hypothesis. The results show that service quality has a positive and significant effect on brand image, trust, customer satisfaction, and repurchase intention. Price perception also has positive and significant effect on customer satisfaction and repurchase intention. Repurchase intention has also been positively and significantly affected by trust and customer satisfaction. While brand image has a positive but not significant effect on repurchase intention. The results also show that service quality through customer satisfaction has the most significant impact on repurchase intention. Thus, in order to increase repurchase intention, GO-JEK needs to increase service quality and customer satisfaction.
\end{abstract}

Keywords: Service Quality, Price Perception, Repurchase Intention.

\section{Introduction}

Traffic congestion in Indonesia, especially in its large cities, is an unavoidable condition, either on the main routes or the alternative routes. It is also undeniable that traffic congestion continues to deteriorate. Many people have been doing many things to cope with it. Semarang is one of Indonesia's large cities that is experiencing traffic congestion.

A transportation service that is able to drive through traffic congestion needs to be developed. A motorcycle taxi is one of the transportation services that is considered effective and in accordance with the lifestyle of most people with a high mobility. By using a motorcycle taxi, people can easily find alternative routes and arrive at the destination quickly.

In this digital era, businessmen are more motivated to continue contributing and doing innovation for the economic development in Indonesia. Online motorcycle taxi service is one example of a creative innovation, which has a sizable market opportunity. 
GO-JEK Indonesia Inc., as known as GO-JEK, is a company that provides transportation, delivery, and shopping services by ordering online. GO-JEK implements B2C (Business to Consumer) E-Commerce by letting the customers order online through the application on smartphones. The presence of GO-JEK has offered solution for several problems such as price transparency, ease of ordering, guaranteed security, etc.

GO-JEK has implemented various strategies to improve service quality, enhance and maintain a good brand image as a pioneer of online motorcycle taxi service, increase customer satisfaction, build trust, and set price that suits customers' perception. So, GO-JEK will be able to increase customers' intention to repurchase.

By considering customer satisfaction, the company can see how well the products have been marketed. Have the products met customers' expectations ? The satisfied customers will show post-purchase behaviour, these customers will make repeat purchases. (Ardiansyah, 2016).

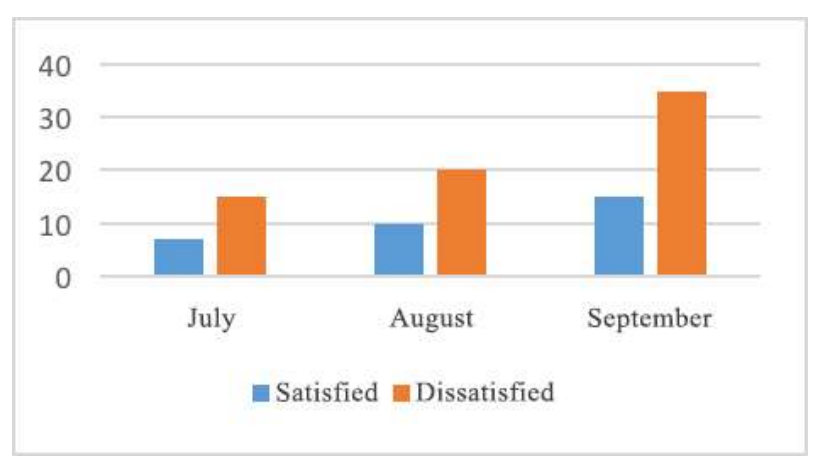

Figure 1. Customer Satisfaction Data of GO-JEK from July to September 2016 (Source:Facebook and Twitter of GO-JEK)

In July 2016, five customers are satisfied and fifteen customers are dissatisfied with the service of GO-JEK. Here, customers are satisfied with GO-CLEAN, GO-FOOD, GOSEND, and GO-RIDE. While the dissatisfaction is mostly caused by the application of GOJEK that contains too much errors. GO-JEK has clarified that the company has been repairing the system that leads to an inaccessible application. In August 2016, ten customers are satisfied and twenty customers are dissatisfied. Customer satisfaction is caused by several things such as GO-JEK is able to assist in the delivery of goods quickly and safely, GOMASSAGE, GO-CAR, and price that suits the services given. While the dissatisfaction increases, which is mostly caused by the difficulty in finding drivers or a lot of them cancel the order. This might be caused by the changing system of GO-JEK that currently applies 'performance' system for the drivers, which makes the drivers refuse to serve the customers. In September 2016, fifteen customers are satisfied and the dissatisfied customers reach thirtyfive. It appears that the number of dissatisfied customers rises quite sharply. The rising dissatisfaction is caused by the drivers who are on strike, because they refuse to accept the new system that GO-JEK has applied, so the orders become neglected.

When the company regulations are not in accordance with what the employees want, this can lead to a strategy implementation failure in maintaining customer relationships. One of the reasons why customers are unwilling to reuse the service from a company is because they receive a poor service quality. When customers feel disappointed or dissatisfied, they will think twice before purchasing the same products from the company. Strategy 
implementation failure can lead to a decreased customer's trust. The price set by the company can also affect customers' intention to repurchase. Thus, the problem arising from this study is how to increase repurchase intention through service quality, brand image, customer satisfaction, trust, and price perception.

\section{Literature Review and Hypothesis}

\section{The Effect of Service Quality on Brand image}

According on the research conducted by Alhaddad (2015), in the service industry, companies are required to provide excellent quality since customers will form a direct perception of the brand image of the company. Research conducted by Caniago, et. al. (2014) states that an outstanding service quality tends to have a good brand image. The result of that research indicates a significant influence between service quality and brand image. The better the service quality of a company, the better the brand image. Similar result was found by Saleem and Raja (2014), where service quality can significantly affect brand image. Companies in the service industry need to focus on the service quality to build a good brand image.

H1: Service quality has a positive impact on brand image

\section{The Effect of Service Quality on Trust}

Research conducted by $\mathrm{Cho}$ and $\mathrm{Hu}$ (2009) states that service quality plays a significant role in building customers' trust. Service quality has a significant and positive impact on customers' trust. Next, research conducted by Halim, et. al. (2014) also states that service quality has a significant impact on customers' trust. Rasheed and Abadi (2014) agrees that there is a positive impact between service quality and trust. By improving service quality, it will also increase customers' trust.

H2: Service quality has a positive impact on trust

\section{The Effect of Service Quality on Customer Satisfaction}

According to the research conducted by Vigripat and Chan (2007), there is a positive and significant relationship between service quality and customer satisfaction. Service quality has an effect in building customer satisfaction. The research conducted by Caniago, et. al. (2014) shows that service quality directly affects customer satisfaction. The better the service quality, it will give a positive impact on customer satisfaction. Ardiansyah (2016) says that service quality also affects the evaluation process of customers in measuring their satisfaction. When the service quality meets or exceeds customers' expectations, customers will be satisfied with the service quality of the company. He also agrees that service quality has a positive and significant effect on customer satisfaction.

H3: Service quality has a positive impact on customer satisfaction

\section{The Effect of Service Quality on Repurchase Intention}

Faradiba and Astuti (2013) state that there is a positive impact between service quality and repurchase intention. The better the service quality, customers' interntion to repurchase will increase. According to Ardiansyah (2016), intention to repurchase will come up after a customer gives a positive feedback on a product that they have received. Research conducted 
by Aryadhe and Rastini (2016) also indicates that there is a positive and significant impact between service quality and repurchase intention, either simultaneously or partially.

H4: Service quality has a positive impact on repurchase intention

\section{The Effect of Customer Satisfaction on Repurchase Intention}

According to Kyauk and Chaipoopirutana (2014), customer satisfaction has a positive and significant impact on repurchase intention. Ebrahimi and Tootoonkavan (2014) agree that when the customer satisfaction is high, the possibility to repurchase will also be high. Ardiansyah (2016) also indicates the same result. He claims that customer satisfaction is the outcome of the quality received by customers that meets their expectations. Customer satisfaction is said to have a positive and significant impact on repurchase intention. If the customers feel satisfied, they will be likely to repurchase.

H5: Customer satisfaction has a positive impact on repurchase intention

\section{The Effect of Brand Image on Trust}

Research has shown that brand image has a significant impact on trust (Prasetya, et. al., 2014). A good brand image will increase the trust of the customers. When a brand already has a good image in customers' mind, the customers are more likely to create positive thoughts on products made by that company. This shows that the customers trust the company. Halim, et. al. (2014) also implies the same thing, where brand image has a significant impact on trust. Alhaddad (2015) says that brand image is an important thing in building trust. His research shows that brand image has a significant and positive impact on trust.

\section{H6: Brand image has a positive impact on trust}

\section{The Effect of Brand Image on Repurchase Intention}

Research conducted by Park, et. al. (2006) tested the effect of brand image on repurchase intention. The research shows that brand image has a positive impact on repurchase intention. When the customers have a positive thought on a brand, they are more likely to repurchase. Lawu (2015) shows that brand loyalty, brand association, brand awareness, quality perception, and brand image have a significant impact on repurchase intention simultaneously. Brand image also has a significant impact on repurchase intention partially. Aryadhe and Rastini (2016) state that there is a positive and significant impact between brand image and repurchase intention, either simultaneously or partially. When the customers prefer one brand, they are more likely to repurchase products made by that company.

H7: Brand image has a positive impact on repurchase intention

\section{The Effect of Trust on Repurchase Intention}

Ebrahimi and Tootoonkavan (2014) show that trust has a direct and positive impact on repurchase intention. Vigripat and Chan (2007) state that the higher the trust, the intention to repurchase will also be higher. Giffar (2016) claims that a company always tries to attract customers' attention by doing things such as giving special offers. This happens to be the most effective way in gaining customers' trust on the company. The research also shows that there is a direct and significant impact between trust and repurchase intention.

H8: Trust has a positive impact on repurchase intention 


\section{The Effect of Price Perception on Customer Satisfaction}

According to Park, et. al. (2006), when price perception that customers have suits the price that the company offers, customer satisfaction will increase. Research conducted by Kurniasih (2012) states that there is a strong and significant relationship between price and customer satisfaction. Low price perception often leads to customer satisfaction. Price offered needs to suit the service quality given, so that the customers will not be dissatisfied. Pratiwi and Sutopo (2012) also indicates that price perception has a positive and significant impact on customer satisfaction, either simultaneously or partially.

H9: Price perception has a positive impact on customer satisfaction

\section{The Effect of Price Perception on Repurchase Intention}

Faradiba and Astuti (2013) indicates that price perception has a positive impact on repurchase intention. Price is one of the factors that customers will take into account in making a decision. Park, et. al. (2006) also shows a similar result. Price perception that meets the price offered will increase the intention of the customers to repurchase. Giffar (2016) finds that before purchasing, customers tend to compare the price offered by one company and the other company. After that, they will create a perception about the price that is fit for them. The result of the research shows that there is a direct and significant impact between price perception and repurchase intention.

H10: Price perception has a positive impact on repurchase intention

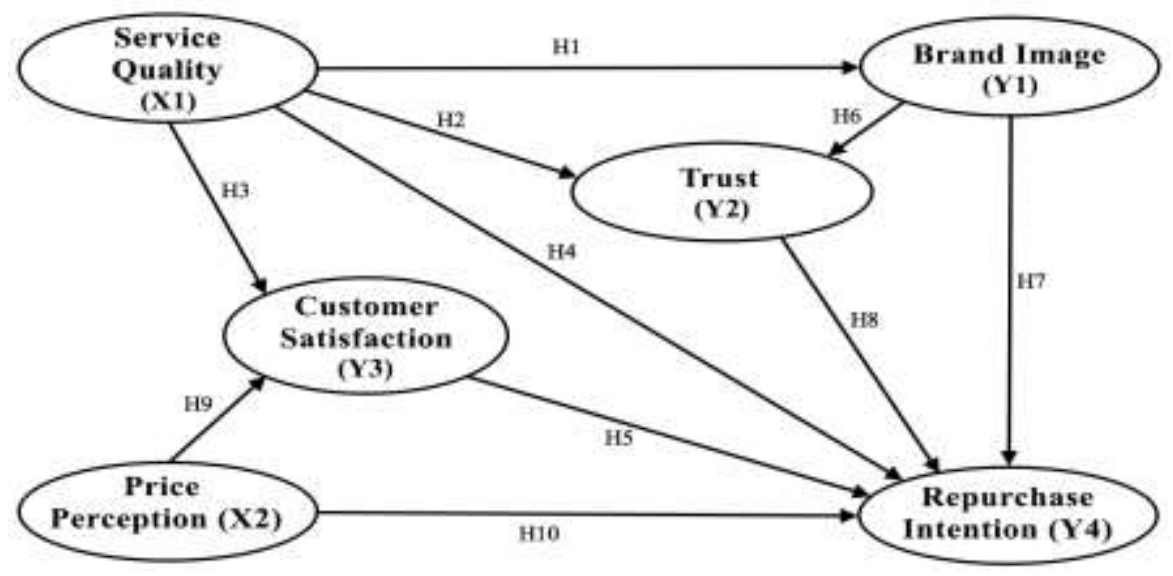

Figure 2. Research Framework (Source: Alhaddad (2015), Ardiansyah (2016), Rasheed \& Abadi (2014), Vigripat \& Chan (2007), Park, et. al. (2006))

\section{Research Method \\ Research Variables}

Independent variable is a variable that has an influence on a dependent variable. This variable affects and is the cause of the emergence of a dependent variable (Sugiyono, 2004). Service Quality (X1) and Price Perception (X2) are the independent variables, as shown in Figure 2. Dependent variable is a variable that is affected or the result of independent variables (Sugiyono, 2004). Repurchase intention (Y4) is the dependent variable. Intervening variable is a variable that theoretically affects the relationship between independent variables 
and the dependent variable. It either weakens or strengthens (Sugiyono, 2004). In this research Brand image (Y1), Trust (Y2), and Customer satisfaction (Y3) are the intervening variables.

Table 1. Variables and Indicators

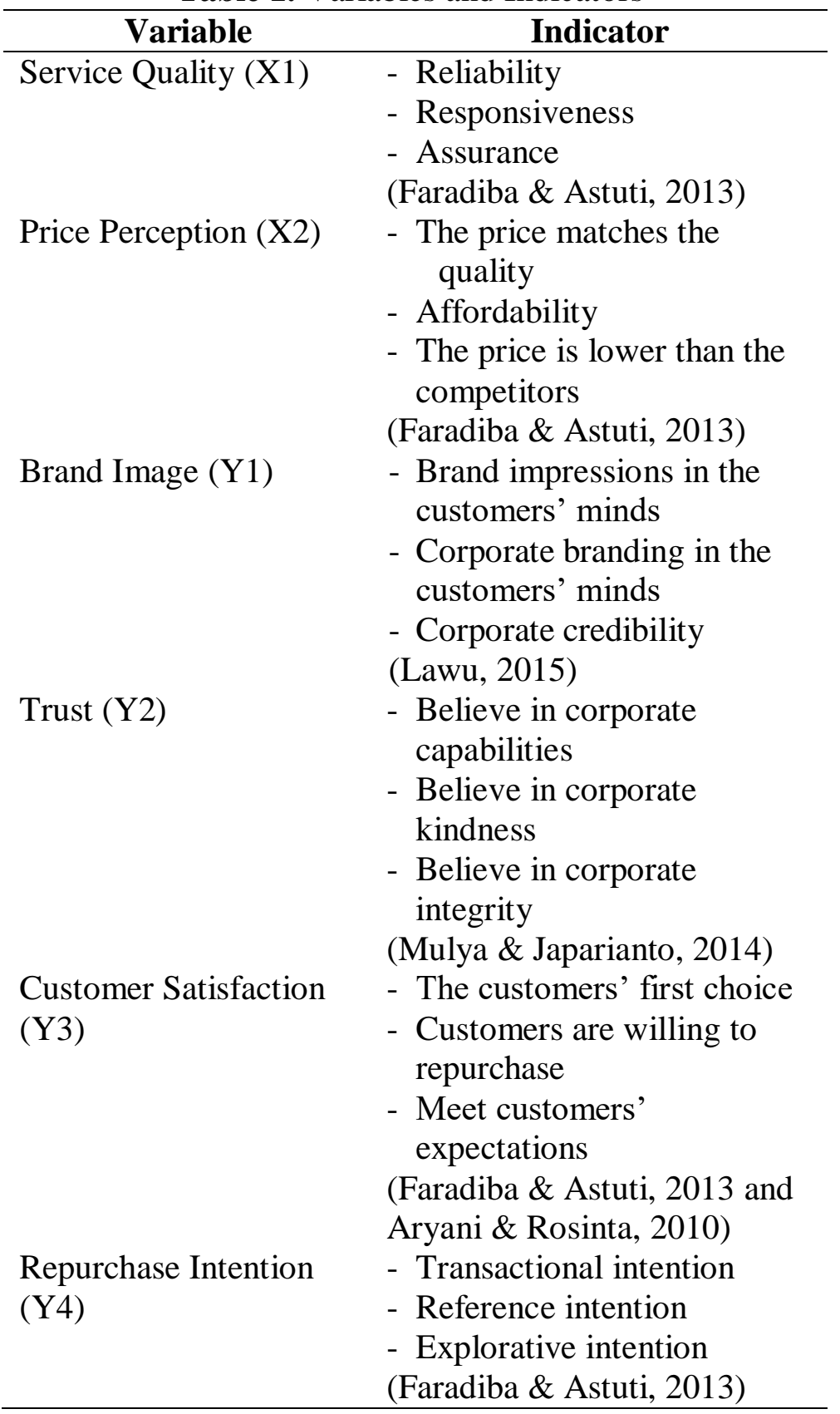

\section{Population and Sample}

The target population in this research are consumers who have ever tried using GOJEK's services in Semarang. Sampling technique used in this research is non-probability sampling. For the methods of collecting data, this research is using purposive sampling. The 
number of samples is 180 samples, which consist of respondents who have ever tried using GO-JEK's services in Semarang more than twice.

\section{Methods of Analysis}

This research is using Structural Equation Modeling (SEM), which is operated by using AMOS 22. The reason to use SEM is because SEM permits complex variable relationships to be expressed through (Ghozali, 2014)

\section{Result and Discussion}

\section{Confirmatory Factor Analysis}

In this step, confirmatory factor analysis on exogeneous and endogeneous variables will be tested separately. Each construct has to be classified and there will be a double-headed arrow $(\leftrightarrow)$ to connect each variable. The first one will be among exogeneous constructs, which are service quality and price perception. The second one will be among endogeneous constructs, which are brand image, trust, customer satisfaction, and repurchase intention.

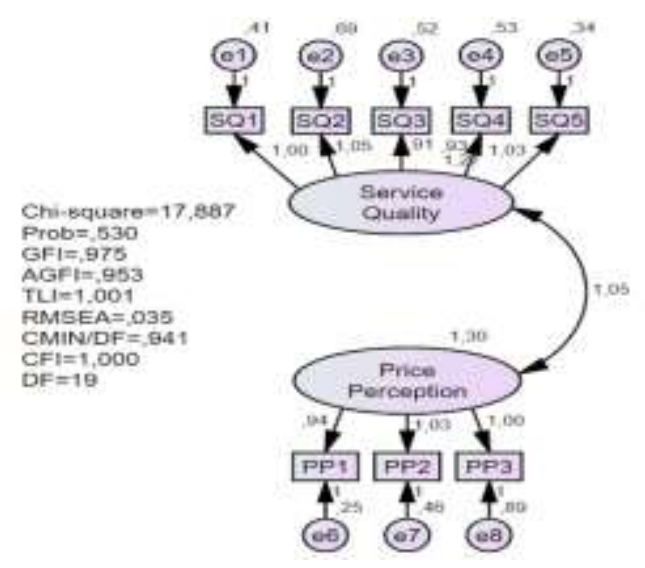

Figure 3. Confirmatory Factor Analysis of Exogeneous Variables (Source: Processed primary data, 2017)

Table 2. Confirmatory Factor Analysis of Exogenous Variables

\begin{tabular}{cccc}
\hline $\begin{array}{c}\text { Goodness } \\
\text { of Fit Index }\end{array}$ & $\begin{array}{c}\text { Cut-Off } \\
\text { Value }\end{array}$ & $\begin{array}{c}\text { Result } \\
\text { Analysis }\end{array}$ & Model Evaluation \\
\hline Chi-Square & df:19; p5\% & 17.887 & Fit \\
& $=30.144$ & & \\
Probability & $>0,05$ & 0.530 & Fit \\
CMIN/DF & $<2.00$ & 0.941 & Fit \\
GFI & $>0,90$ & 0.975 & Fit \\
AGFI & $>0.90$ & 0.953 & Fit \\
TLI & $>0.90$ & 1.001 & Fit \\
CFI & $>0.90$ & 1,000 & Fit \\
RMSEA & $\leq 0.08$ & 0.035 & Fit \\
\end{tabular}

Source: Processed primary data, 2017 
Table 3. Regression Weights of Exogenous Variables

\begin{tabular}{llrrrrl}
\hline & & Estimate & S.E. & C.R. & P & Label \\
\hline SQ1 <--- & Service_Quality & 1.000 & & & & \\
SQ3 <--- & Service_Quality & .911 & .064 & 14.149 & $* * *$ & par_1 \\
SQ5 <--- & Service_Quality & 1.028 & .062 & 16.692 & $* * *$ & par_2 \\
SQ2 <--- & Service_Quality & 1.052 & .075 & 14.051 & $* * *$ & par_3 \\
SQ4 <--- & Service_Quality & .932 & .066 & 14.165 & $* * *$ & par_4 \\
PP3 <--- & Price_Perception & 1.000 & & & & \\
PP2 <--- & Price_Perception & 1.025 & .082 & 12.456 & $* * *$ & par_5 \\
PP1 <--- & Price_Perception & .942 & .074 & 12.685 & $* * *$ & par_6 \\
\hline
\end{tabular}

Source: Processed primary data, 2017

Table 2 shows that the value of the Chi-Square, which is 17.887 , is fit because it is smaller than the suggested value in the Chi-Square table, which is 30.144. Other results show that the value of CMIN/DF, GFI, AGFI, TLI, CFI, and RMSEA are also in accordance with the cut-off value. So it can be concluded that the model can be used to describe the causal relationship between the exogenous variables properly.

From Table 3, it can be seen that the Critical Ratio (C.R.) for each indicator has qualified, which is greater than 1.96. The loading factors of each indicator in Figure 4 has also qualified, which is greater than 0.40 . So it can be concluded that these indicators are significantly the dimensions of the latent variables which have been formed.

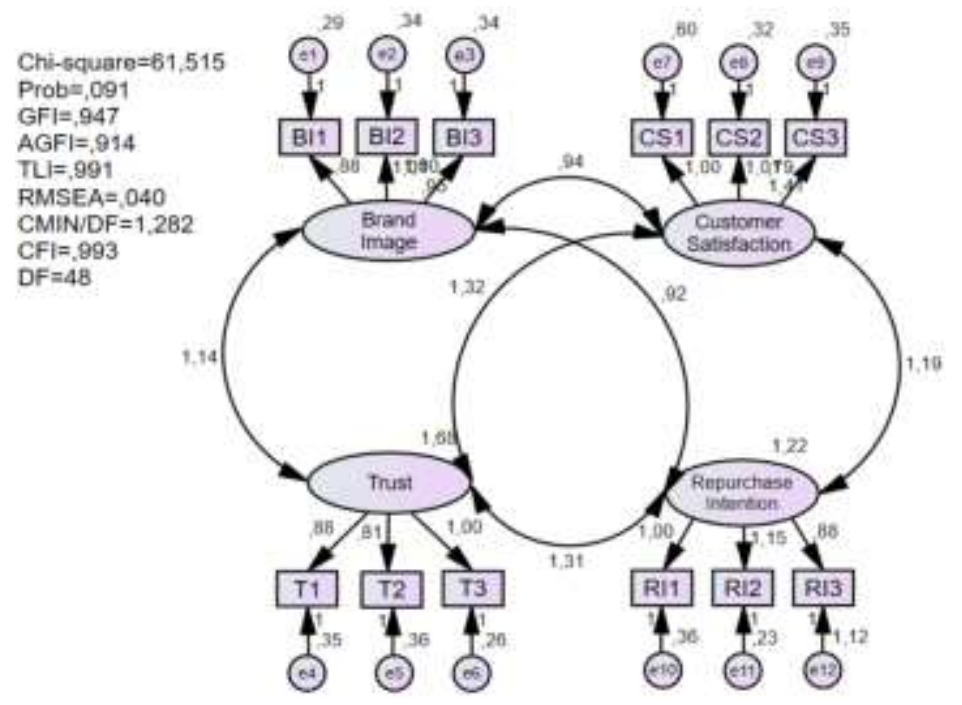

Figure 4. Confirmatory Factor Analysis of Endogenous Variables (Source: Processed primary data, 2017) 
Table 4. Confirmatory Factor Analysis of Endogenous Variables

\begin{tabular}{cccc}
\hline $\begin{array}{c}\text { Goodness of } \\
\text { Fit Index }\end{array}$ & $\begin{array}{c}\text { Cut-Off } \\
\text { Value }\end{array}$ & $\begin{array}{c}\text { Result } \\
\text { Analysis }\end{array}$ & $\begin{array}{c}\text { Model } \\
\text { Evaluation }\end{array}$ \\
\hline Chi-Square & $\begin{array}{c}\text { df: } 48 ; \text { p5\% } \\
65.171\end{array}$ & 61.515 & Fit \\
Probability & $>0.05$ & 0.091 & Fit \\
CMIN/DF & $<2.00$ & 1.282 & Fit \\
GFI & $\geq 0.90$ & 0.947 & Fit \\
AGFI & $>0.90$ & 0.914 & Fit \\
TLI & $>0.90$ & 0.991 & Fit \\
CFI & $>0.90$ & 0.993 & Fit \\
RMSEA & $\leq 0.08$ & 0.040 & Fit \\
\hline
\end{tabular}

Source: Processed primary data, 2017

Table 5. Regression Weights of Endogenous Variables

\begin{tabular}{|c|c|c|c|c|c|c|c|}
\hline & & & $\begin{array}{r}\text { Estim } \\
\text { ate }\end{array}$ & S.E. & C.R. & $\mathrm{P}$ & Label \\
\hline CS1 & $<--$ & Customer_Satisfaction & 1.000 & & & & \\
\hline $\mathrm{CS} 2$ & $<---$ & Customer_Satisfaction & 1.014 & .065 & 15.564 & $* * *$ & par_1 \\
\hline CS3 & $<---$ & Customer_Satisfaction & .792 & .057 & 13.839 & $* * *$ & par_2 \\
\hline RI2 & $<--$ & Repurchase_Intention & 1.150 & .062 & 18.622 & $* * *$ & par_3 \\
\hline RI3 & $<---$ & Repurchase_Intention & .877 & .083 & 10.522 & $* * *$ & par_4 \\
\hline RI1 & $<---$ & Repurchase_Intention & 1.000 & & & & \\
\hline $\mathrm{T} 1$ & $<---$ & Trust & .881 & .045 & 19.418 & $* * *$ & par_5 \\
\hline $\mathrm{T} 2$ & $<---$ & Trust & .808 & .044 & 18.455 & $* * *$ & par_6 \\
\hline $\mathrm{T} 3$ & $<---$ & Trust & 1.000 & & & & \\
\hline BI1 & $<---$ & Brand_Image & .885 & .061 & 14.390 & $* * *$ & par_7 \\
\hline $\mathrm{BI} 2$ & $<---$ & Brand_Image & 1.010 & .069 & 14.619 & $* * *$ & par_8 \\
\hline $\mathrm{BI} 3$ & $<---$ & Brand_Image & 1.000 & & & & \\
\hline
\end{tabular}

Table 4 shows that the value of the Chi-Square, which is 61.515 , is fit because it is smaller than the suggested value in the Chi-Square table, which is 65.171. Other results show that the value of CMIN/DF, GFI, AGFI, TLI, CFI, and RMSEA are also in accordance with the cut-off value. So it can be concluded that the model can be used to describe the causal relationship between the endogenous variables properly.

From Table 5, it can be seen that the Critical Ratio (C.R.) for each indicator has qualified, which is greater than 1.96. The factor loading of each indicator in Figure 4 has also qualified, which is greater than 0.40 . So it can be concluded that these indicators are significantly the dimension soft the latent variables which have been formed. 


\section{Structural Equation Model (SEM)}

Figure 5. Full Structural Model

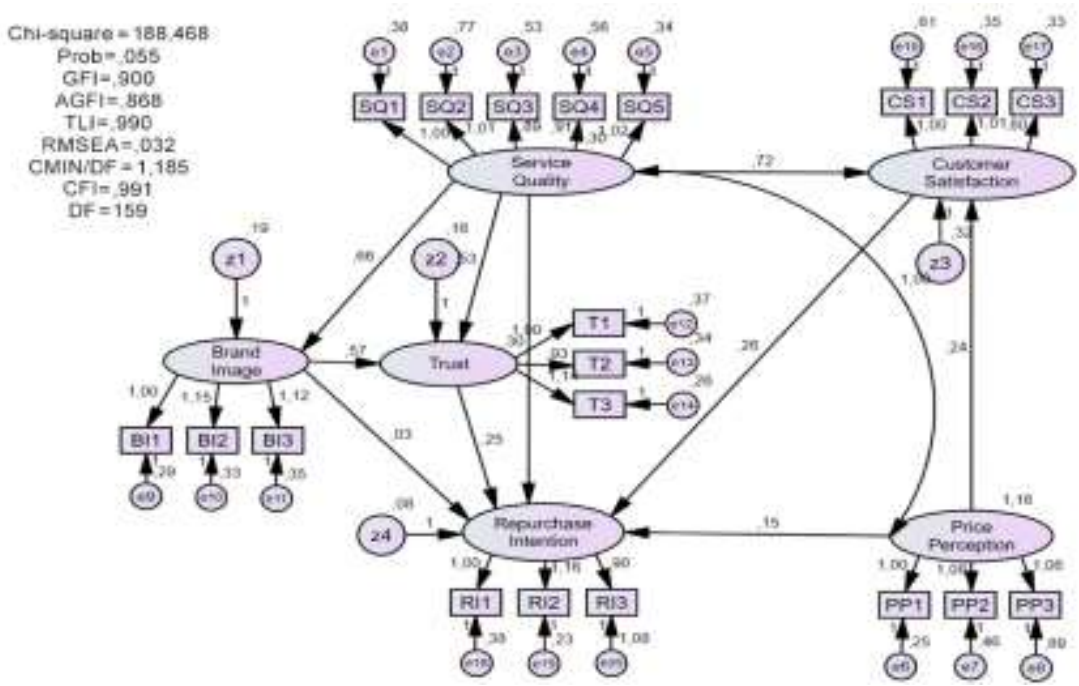

Source: Processed primary data, 2017

Table 6. Full Structural Model

\begin{tabular}{lccc}
\hline $\begin{array}{c}\text { Goodness of Fit } \\
\text { Index }\end{array}$ & Cut-Off Value & $\begin{array}{c}\text { Result } \\
\text { Analysis }\end{array}$ & $\begin{array}{c}\text { Model } \\
\text { Evaluatio }\end{array}$ \\
\hline Chi-Square & df:159; p5\% & 188.468 & Fit \\
& 189.424 & & \\
Probability & $>0.05$ & 0.055 & Fit \\
CMIN/DF & $<2.00$ & 1.185 & Fit \\
GFI & $>0.90$ & 0.900 & Fit \\
AGFI & $>0.90$ & 0.868 & Fit \\
TLI & $>0.90$ & 0.990 & Fit \\
CFI & $\leq 0.90$ & 0.991 & Fit \\
RMSEA & $\leq 0.08$ & 0.032 & Fit \\
\hline
\end{tabular}

Source: Processed primary data, 2017

Table 7. Regression Weights of Full Structural Model

\begin{tabular}{lllllll}
\hline & & Estimate & S.E. & C.R. & P & Label \\
\hline Brand_Image & $<---$ & Service_Quality & .656 & .052 & 12.534 & $* * *$ par_2 \\
$\begin{array}{l}\text { Trust } \\
\begin{array}{l}\text { Customer_Sati } \\
\text { sfaction }\end{array}\end{array}$ & B--- & Service_Quality & .718 & .107 & 6.715 & $* * *$ par_3 \\
\hline
\end{tabular}




\begin{tabular}{|c|c|c|c|c|c|c|c|}
\hline & & & Estimate & S.E. & C.R. & $\mathrm{P}$ & Label \\
\hline $\begin{array}{l}\text { Customer_Sati } \\
\text { sfaction }\end{array}$ & $<--$ & Price_Perception & .240 & .108 & 2.229 & .026 & par_4 \\
\hline Trust & $<--$ & Service_Quality & .530 & .098 & 5.382 & $* * *$ & par_22 \\
\hline $\begin{array}{l}\text { Repurchase_I } \\
\text { ntention }\end{array}$ & $<--$ & Brand_Image & .032 & .133 & .244 & .807 & par_15 \\
\hline $\begin{array}{l}\text { Repurchase_I } \\
\text { ntention }\end{array}$ & $<--$ & Price_Perception & .148 & .072 & 2.041 & .041 & par_19 \\
\hline $\begin{array}{l}\text { Repurchase_I } \\
\text { ntention }\end{array}$ & $<--$ & Service_Quality & .301 & .131 & 2.299 & .022 & par_20 \\
\hline $\begin{array}{l}\text { Repurchase_I } \\
\text { ntention }\end{array}$ & $<--$ & Trust & .254 & .124 & 2.048 & .041 & par_21 \\
\hline $\begin{array}{l}\text { Repurchase_I } \\
\text { ntention }\end{array}$ & $<---$ & $\begin{array}{l}\text { Customer_Satisf } \\
\text { action }\end{array}$ & .259 & .083 & 3.108 & .002 & par_24 \\
\hline
\end{tabular}

Source: Processed primary data, 2017

\section{Hypothesis Testing}

Hypothesis testing is done by checking if the Critical Ratio (C.R.) and Probability (P) value from the processed data fit the required value. The required value for C.R. is greater than 1.96 and for $\mathrm{P}$ is smaller than 0.05 . Based on Table 7, it can be seen that all hypothesis are accepted and significants because CR are greater than 1.96 and $\mathrm{P}$ are smaller than 0.05 .

\section{Repurchase Intention Improvement Process}

Table 8. Standardized Direct Effects

\begin{tabular}{|c|c|c|c|c|c|c|}
\hline & Price Perception & Service_Quality & Brand Image & Customer Satisfaction & Trust & Repurchase Intention \\
\hline Brand_Image & 000 & 8666 &, 000 &, 000 &, 000 &, 000 \\
\hline Customer__atisfaction & 217 & ,691 & ,000 & ,000 & , 000 & , 000 \\
\hline Trust & ,000 &, 533 & ,435 & ,000 & , 000 & , 000 \\
\hline Repurchase__ntention &, 146 &, 314 &, 026 & 281 &, 264 &, 000 \\
\hline
\end{tabular}

Source: Processed primary data, 2017

Table 8 shows that the effects of each variable on repurchase intention can be analyzed as follows:

1. The direct effect of service quality on the repurchase intention is 0.314 .

2. The direct effect of price perception on repurchase intention is 0.146 .

3 . The direct effect of service quality on brand image is 0.866 . The direct effect of brand image on repurchase intention is 0.026 . So the effect of service quality on repurchase intention through brand image is $0.866 \times 0.026=0.023$.

4. The direct effect of service quality on brand image is 0.866 . The direct effect of brand image on trust is 0.435 . The direct effect of trust on repurchase intention is 0.264 . So 
the effect of service quality on repurchase intention through brand image and trust is $0.866 \times 0.435 \times 0.264=0.100$.

5. The direct effect of service quality on trust is 0.533 . The direct effect of trust on repurchase intention is 0.264 . So the effect of service quality on repurchase intention through trust is $0.533 \times 0.264=0.141$.

6. The direct effect of service quality on customer satisfaction is 0.691 . The direct effect of customer satisfaction on repurchase intention is 0.281. So the effect of service quality on repurchase intention through customer satisfaction is $0.691 \times 0.281=$ 0.194 .

7. The direct effect of price perception on customer satisfaction is 0.217 . The direct effect of customer satisfaction on repurchase intention is adalah 0.281. So the effect of price perception on repurchase intention through customer satisfaction is $0.217 \mathrm{x}$ $0.281=0.061$.

According to the analyzed above, increasing repurchase intention can be done in several ways, such as:

1. Improving service quality directly. Its effect on repurchase intention is 0.314 .

2. Improving service quality in order to increase customer satisfaction. Its effect on repurchase intention is 0.194 .

3. Improving price perception directly. Its effect on repurchase intention is 0.146 .

4. Improving service quality in order to build trust. Its effect on repurchase intention is 0.141 .

5. Improving service quality in order to enhance brand image, which will increase trust. Its effect on repurchase intention is 0.100 .

6. Improving price perception in order to increase customer satisfaction. Its effect on repurchase intention is 0.061 .

7. Improving service quality in order to enhance brand image. Its effect on repurchase intention is 0.023 .

\section{Conclusion and Managerial Implication \\ Conclusion}

According to the result, it can be concluded that:

1. A better brand image can be directly affected by service quality. The result shows that service quality has a positive and significant impact on brand image. This result empirically strengthens the research conducted by Alhaddad (2015). The research finds that a strong service quality tends to have a good brand image.

2. An increased trust can be directly affected by service quality and brand image. This result empirically strengthens the research conducted by Rasheed and Abadi (2014). The research claims that by improving the service quality, the trust will also be increased. The result also empirically strengthens the research conducted by Alhaddad (2015). The result shows that a good brand image will increase the trust of the customers.

3. An increased customer satisfaction can be directly affected by service quality and price perception. From two variables, service quality has a dominant impact on customer satisfaction compared to price perception. It is proven that customers still prefer to have a better service quality rather than a lower price. The result empirically strengthens the research conducted by Vigripat and Chan (2007), which states that the 


\section{Mudiantono, Debrina Andhike}

better the service quality, it will give a positive impact on customer satisfaction. This result also empirically strengthens the research conducted by Park et al. (2006). Price offered by the company has to suit the service quality that will be given. Because the better the price perception, it will increase customer satisfaction.

4. An increased repurchase intention can be affected by service quality and price perception, either directly or indirectly. Service quality affects repurchase intention significantly and indirectly through trust and customer satisfaction. Service quality also affects repurchase intention through brand image, but the impact is insignificant. While price perception affects repurchase intention indirectly through customer satisfaction. This result empirically strengthens the research conducted by Ardiansyah (2016). The research shows that a good service quality will increase customers' intention to repurchase. If customers feel satisfied with the service, they are more likely to use the service in the future. The result also empirically strengthens the research conducted by Vigripat and Chan (2007), which explains that the higher the trust, the intention to repurchase will also be higher. Research conducted by Park et al. (2006) indicates that when price perception suits the price offered, the intention to repurchase will be increased.

\section{Managerial Implication}

Based on the conclusions that have been made, there are several implications, such as:

1. Improving service quality directly. There are several ways to improve the service quality of GO-JEK. First, the drivers need to be trained to master some specific places and alternative routes. Second, after receiving the order, it is better for the drivers to confirm, so there will not be any miscommunication. Third, before picking up the customers, it is better for the drivers to ensure that the equipments such as helmet, face and head mask, raincoat, etc. are provided.

2. Improving customer satisfaction in order to improve service quality and price perception. There are several ways to improve customer satisfaction. First, GO-JEK needs to intensify the promotion on some services that are least desirable, so that people will be interested to try the services, get the benefits, and make them as the first choice. Next, GO-JEK needs to ensure that the services already meet the needs of the people. GO-JEK also needs to consider the welfare of the drivers, because drivers will be the ones who are interacting with customers. So they might be the ones who determine customer satisfaction. Last, GO-JEK is advised to conduct more training for the drivers to improve the service quality. Because a good service quality will better meet customers' expectations.

3. Increasing trust in order to improve service quality and brand image. There are several ways to improve trust. First, GO-JEK needs to ensure that the drivers always strive to give an accurate service. Second, GO-JEK also needs to ensure whether the service already meets the needs of the customers, whether the security is guaranteed, and so on. Third, before partnering with the drivers, it is better for GO-JEK to always 
ensure their reliability in various aspects, so that the drivers will be able to provide a great service quality.

4. Improving price perception directly. There are several ways to improve price perception. GO-JEK still needs to maintain a good service quality although the price offered is relatively low. GO-JEK also needs to find a way to reach customers who are having difficulties to top up for GO-PAY, so that the price remains affordable. Looking at the sufficient number of competitors in the form of traditional motorcycle taxi and conventional taxi in Semarang, it is better for GO-JEK to intensify the promotion.

5. Enhancing brand image in order to improve service quality. There are several ways to enhance or maintain a good brand image. First, GO-JEK has to continue giving the best service quality. Next, it is better for GO-JEK to do unique promotions to attract customers. Last, GO-JEK needs to always consider the needs and wants of the people, so that they will consistently be a trustworthy company.

\section{References}

Alhaddad, A. 2015. "Perceived Quality, Brand Image and Brand Trust as Determinants of Brand Loyalty". Journal of Research in Business and Management, Vol. 3, No. 4, p. $1-8$.

Ardiansyah, L. 2016. "Pengaruh Kualitas Pelayanan terhadap Kepuasan Pelanggan dan Minat Pembelian Ulang Jasa Maskapai Penerbangan Lion Air". Jurnal Ilmiah Mahasiswa FEB, Vol. 2, No. 2.

Aryadhe, P. and N. M. Rastini. 2016. "Kualitas Pelayanan, Kualitas Produk dan Citra Merek terhadap Niat Beli Ulang”. E-Jurnal Manajemen Unud, Vol. 5, No.9, p. 5695-5721.

Aryani, D. and F. Rosinta. 2010. "Pengaruh Kualitas Layanan terhadap Kepuasan Pelanggan dalam Membentuk Loyalitas Pelanggan”. Jurnal Ilmu Administrasi dan Organisasi, Vol. 17, No. 2, p. 114-126.

Caniago, A., Suharyono, Z. Arifin, and S. Kumadji. 2014. "The Effects of Service Quality and Corporate Rebranding on Brand Image, Customer Satisfaction, Brand Equity and Customer Loyalty”. European Journal of Business and Management, Vol. 6, No. 19, p. 118-126.

Cho, J. E. and H. Hu. 2009. "The Effect of Service Quality on Trust and Commitment Varying Across Generations". International Journal of Consumer Studies, Vol. 33, No. 4, p. 468-476.

Ebrahimi. M. R. and S. Tootoonkavan. 2014. "Investigating the Effect of Perceived Service Quality, Perceived Value, Brand Image, Trust, Customer Satisfaction on Repurchase Intention and Recommendation to Other". European Journal of Business and Management, Vol. 6, No. 34, p. 181-186.

Faradiba and S. R. T. Astuti. 2013. "Analisis Pengaruh Kualitas Produk, Harga, Lokasi dan Kualitas Pelayanan terhadap Minat Beli Ulang Konsumen”. Diponegoro Journal of Management, Vol. 2, No. 3, p. 1-10.

Ghozali, I. 2014. Konsep dan Aplikasi dengan Program AMOS 22.0. Semarang: Badan Penerbit Universitas Diponegoro. 
Giffar, D. 2016. "Peran Iklan, Brand Image, Price, Trust, dan Perceived Value terhadap Repurchase Intention". Jurnal Ilmiah Mahasiswa FEB, Vol. 4, No. 1.

Halim, P., B. Swasto, D. Hamid, and M. R. Firdaus. 2014. "The Influence of Product Quality, Brand Image, and Quality of Service to Customer Trust and Implication on Customer Loyalty". European Journal of Business and Management, Vol. 6, No. 29, p. 159-166.

Kurniasih, I. D. 2012. "Pengaruh Harga dan Kualitas Pelayanan terhadap Loyalitas Pelanggan Melalui Variabel Kepuasan”. Jurnal Administrasi Bisnis, Vol. 1, No. 1, p. $37-45$.

Kyauk, S. T. and S. Chaipoopirutana. 2014. "Factors Influencing Repurchase Intention". International Conference on Trends in Economics, Humanities and Management, No. 37, p. 177-180.

Lawu, B. J. L. 2015. "Pengaruh Elemen Brand Knowledge dan Brand Equity terhadap Repurchase Intention". Jurnal Manajemen, Vol. 14, No. 2, p. 197-222.

Mulya, A. C. and E. Japarianto. 2014. "Analisa Persepsi Pelanggan terhadap Kinerja Agen Properti dan Pengaruhnya terhadap Kepercayaan di Surabaya". Jurnal Manajemen Pemasaran Petra, Vol. 2, No. 1, p. 1-8.

Park, J., R. Robertson, and C. Wu. 2006. "Modelling the Impact of Airline Service Quality and Marketing Variables on Passengers' Future Behavioural Intentions". Transportation Planning and Technology, Vol. 29, No. 5, p. 359-381.

Prasetya, C. H. A., S. Kumadji, and E. Yulianto. 2014. "Pengaruh Citra Merek, Kualitas Produk terhadap Kepercayaan serta Keputusan Pembelian”. Jurnal Administrasi Bisnis, Vol. 15, No. 2, p. 1-6.

Pratiwi, A. D. and Sutopo. 2012. "Pengaruh Kualitas Layanan dan Harga Tiket terhadap Kepuasan Pelanggan Pengguna Jasa Kereta Api Kaligung Mas Kelas Eksekutif pada PT. KAI Daop 4 Semarang”. Diponegoro Journal of Management, Vol. 1, No. 2, p. 267-273.

Rasheed, F. A. and M. F. Abadi. 2014. "Impact of Service Quality, Trust and Perceived Value on Customer Loyalty in Malaysia Services Industries”. Procedia - Social and Behavioral Sciences, Vol. 164, p. 298-304.

Saleem, H. and N. S. Raja. 2014. "The Impact of Service Quality on Customer Satisfaction, Customer Loyalty and Brand Image". IOSR Journal of Business and Management, Vol. 16, No. 1, p. 117-122.

Sugiyono. 2004. Metode Penelitian Bisnis. Bandung: Alfabeta.

Vigripat, T. and P. Chan. 2007. "An Empirical Investigation of the Relationship Between Service Quality, Brand Image, Trust, Customer Satisfaction, Repurchase Intention and Recommendation to Others". Journal: International DSI, Asia and Pacific DSI 2007 Full Paper, July, p. 1-15. 